\title{
Analysis of stomach content of piscivorous fishes caught in Danau Panggang Peatland, South Kalimantan, Indonesia
}

\author{
DINI SOFARINI ${ }^{1,2, \vartheta}$, ENDANG YULI HERAWATI ${ }^{3}$, MOHAMMAD MAHMUDI $^{3}$, \\ ASUS MAIZAR SURYANTO HERTIKA ${ }^{3}$, DIANA ARFIATI ${ }^{3}$, MUHAMMAD MUSA ${ }^{3}$, MOHAMAD AMIN ${ }^{4}$, \\ SUPRIHARYONO \\ ${ }^{1}$ Doctoral Program of Fisheries and Marine Science, Universitas Brawijaya. Jl. Veteran, Malang 65145, East Java, Indonesia. \\ Tel./fax.: +62-341-553512, `email: dini.sofarini@ulm.ac.id. \\ ${ }^{2}$ Department of Aquatic Resource Management, Universitas Lambung Mangkurat. Jl. A. Yani Km. 36.6, Simpang Empat, Banjarbaru 70714, South \\ Kalimantan, Indonesia. \\ ${ }^{3}$ Department of Aquatic Resource Management, Faculty of Fisheries and Marine Science, Universitas Brawijaya. J1. Veteran, Malang 65145, East Java, \\ Indonesia \\ ${ }^{4}$ Department of Biology, Faculty of Mathematics and Natural Sciences, Universitas Negeri Malang. Jl. Semarang, Malang 65145, East Java, Indonesia. \\ ${ }^{5}$ Faculty of Fisheries and Marine Science, Universitas Diponegoro. Jl. Prof. H. Soedarto, S.H, Tembalang, Semarang 50275, Central Java, Indonesia
}

Manuscript received: 24 August 2019. Revision accepted: 28 November 2019

\begin{abstract}
Sofarini D, Herawati EY, Mahmudi M, Hertika AMS, Arfiati D, Musa M, Amin M, Supriharyono. 2019. Analysis of stomach content of piscivorous fishes caught in Danau Panggang Peatland, South Kalimantan, Indonesia. Biodiversitas 20: 3788-3793. The purpose of this study was to analyze the stomach content profile of piscivorous fishes caught at the reservaat station and the station without activity as The control station, in the Danau Panggang peatland. Sampling was carried out four times and the index of preponderance stomach content was determined in piscivorous fishes. The results showed there were nine fish species in the reservaat area, including Cryptopterus spp., Pangasius nieuwenhuisii, Chana striata, Anabas testudineus, Pangasius sp., Mastecembelus erythrotaenia, Macrognathus aculeatus, Mystus nigriceps, and Mystus nemurus. Their gut was dominated 89\% by Chrysophyta, and $37.5 \%$ by Diatom and Navicula. In the area without activity, six species of fish were caught, including Cryptopterus spp, Pangasius nieuwenhuisii, Anabas testudineus, Pangasius sp, Mystus nigriceps, and Mystus nemurus, with 83\% of their gut dominated by Diatom. The water temperature was $28.07-33.25^{\circ} \mathrm{C}$, brightness $(6-115 \mathrm{~cm}), \mathrm{pH}$ of $4.23-6.97$, dissolved oxygen (DO) (1.4-6.5 mg/L) and BOD $(7.52-24.92 \mathrm{mg} / \mathrm{L})$ i.e., water quality parameters that tend to be incompatible with the persistence of fishes. These limiting factors of peatland water and extreme conditions led to a limitation at availability of natural food for piscivorous fishes.
\end{abstract}

Keywords: Chrysophyta, food habits, index of preponderance, piscivore, water quality

\section{INTRODUCTION}

The index of Preponderance (IP) is used to analyze composition of stomach contents of fishes (Ishii and Tanaka 2001; Effendi 2002; Dubiaski-Silva and Masunari 2008), and also as an indicator of feeding habits (Mohan and Sankaran 1988). In addition, the process of identifying the types of foods consumed by fish, taking cognizance of the main, complementary, and supplementary or substitute items requires an IP calculation. Therefore, this index is also applied in estimating the exchange of energy and ingredients in the ecology of the food chain (Pawson et al. 2007; Moore and de Ruiter 2012; West et al. 2017).

The species of fish that eat plankton or planktivores are divided into two groups including the group that consumes them during (1) the juvenile phase and (2) the adult phase (Mora 2015; Beveridge et al. 2004). These species are often found in the stomach of carnivorous fishes that tend to eat other aquatic vertebrates and invertebrates, i.e. piscivores. This occurrence was due to the ingestion of plankton, phytoplankton, or zooplankton during the activity of hunting, although they generally do not dominate in stomach contents (Sanchez-Gonzales et al. 2001; Scholz and Trepel 2004).
"Danau Panggang" Peatland Waters is a typical peatland that forms thick peat (Noor 2007), characterized by acidic $\mathrm{pH}$, solids suspended by colloidal particles with red and smelly water indicators. This peatland originates from the weathering of organic materials, which is generally contained in black waters areas as humic acid, with $\mathrm{pH}$ below 4 (Scholz and Trepel 2004; Voellmy et al. 2014), although the values range from 3.5-4.5. Sulistiyarto (1998) indicated that the $\mathrm{pH}$ in Berengbengkel Peatland waters, Central Kalimantan fluctuates around 2.8-3.3. A low value was also reported by Beamish and Gao (2003) in the peatland of North Selangor (3.3-5.3). Moreover, the dissolved oxygen content, which is the most important limiting factor for organisms in the aquatic ecosystem, was also low. Danau Panggang Peatland is classified as inland waters, that was closed or isolated typical. The activity of entry and exit water is very minimal so that oxygen becomes saturated and coupled with the activity of biota respiration. Bayurini (2006) reported the dissolved oxygen value in the Rawa Pening Peatland, Central Java to range from 2.33-3.15 mg/L. This condition of the waters is such that only fishes with special adaptation, such as labyrinth organ may persist (Sloman and Wilson 2006). Therefore enabling survival, and also enhancing the chances of 
becoming predators in the food chain (being in the piscivorous group).

The stations used in this study were chosen based on differences in land use, where (i) reservaat $(\mathrm{RV})$ is a conservation area protected and various fishery activities are prohibited, and (ii) non-activity (TA) was an empty land used only as an area for passing water transportations. Therefore, the characteristics of sampling locations should determine the type of natural foods, present and consequent patterns. In addition, the stomach contents of piscivorous fishes were analyzed to determine specific feeding habits.

The purpose of this study, therefore, was to analyze the stomach contents of piscivorous fishes, caught at the RV and TA stations in Danau Panggang Peatland. This was conducted with the condition of water quality that fulfills the quality standards required by the Government Regulation number $82 / 2001$, and the composition of food in the piscivorous fish stomach being $90 \%$ fish (Joyce et al 2002). However, with extreme conditions, at the same or different compositions might become evident.

\section{MATERIALS AND METHODS}

\section{Sampling}

This study was conducted in the Reservaat (RV) and Non-Activity (TA) areas of the Danau Panggang Peatland waters, North Hulu Sungai, South Kalimantan, Indonesia (Figure 1 and 2). Meanwhile, sampling of fish was undertaken 4 times, within July and October 2017, and then January and April 2018, and the population investigated was piscivorous fishes that were caught using cast net.

The samples were separated based on the study stations, and their stomach was extracted by dissection. This was then placed in a film bottle, containing $4 \%$ formalin. The samples were taken to the Laboratory of Water Quality and Hydrobioecology, Faculty of Fisheries and Maritime Affairs, University of Lambung Mangkurat, Banjarmasin, Indonesia. Subsequently, the stomach contents were analyzed as frequency of occurrence, and volumetric method. Therefore, the identification of the food type liked

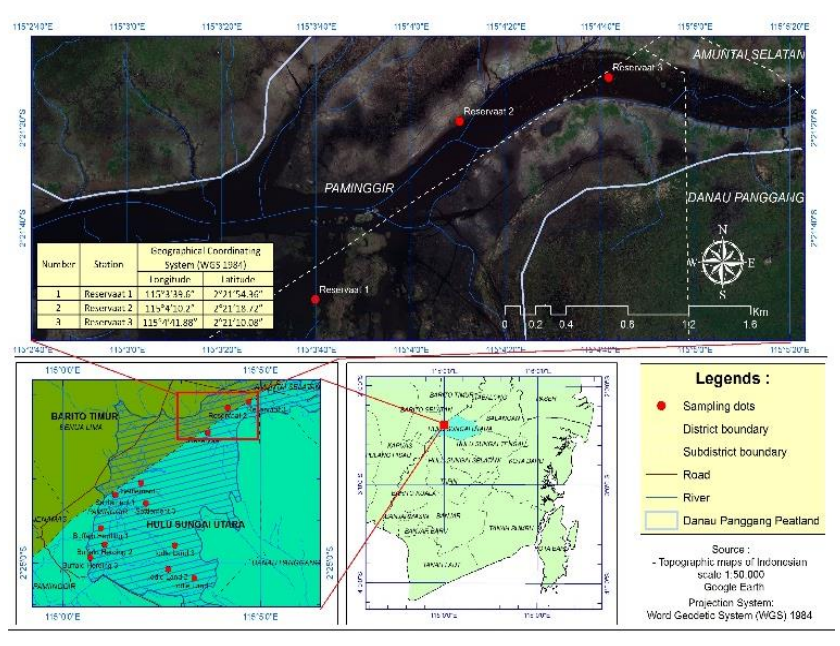

was determined by calculating the Index of Preponderance, which was stated as percentage (Effendi 2002).

\section{Frequency of occurrence method}

The methods of measuring the frequency of occurrence involved noting each of the stomach contents of the fish, which were divided into two groups, including stomachs with and without contents.

$$
O i=\frac{N I}{I} \times 100 \%
$$

Where:

Oi : Frequency of occurrence,

$\mathrm{Ni}$ : The total number of one type of organism,

I : The total of the stomach with contents

\section{Volumetric method}

The volumetric method is aimed to measure fish food, based on the volume of food contained in the stomach.

$$
V i=\frac{96 i}{I} \times 10
$$

Where:

Vi : Volumetric,

$\% \mathrm{i}$ : The total volume of one type of organism in percent

I : The total of the stomach with contents.

\section{Index of preponderance}

This calculation is aimed at evaluating the feeding habits of fish, using a combination of two techniques, including the frequency of occurrence and volumetric methods (Effendi 2002).

$$
I P=\frac{\text { YrXU1 }}{\sum \text { VixOi }} \times 10
$$

Where:

IP : Index of Preponderance,

Vi : Percentage of the volume of the 1 st food, and

Oi : Percentage of occurrence frequency of the 1st food
Figure 1. Reservaat observation station location (RV)

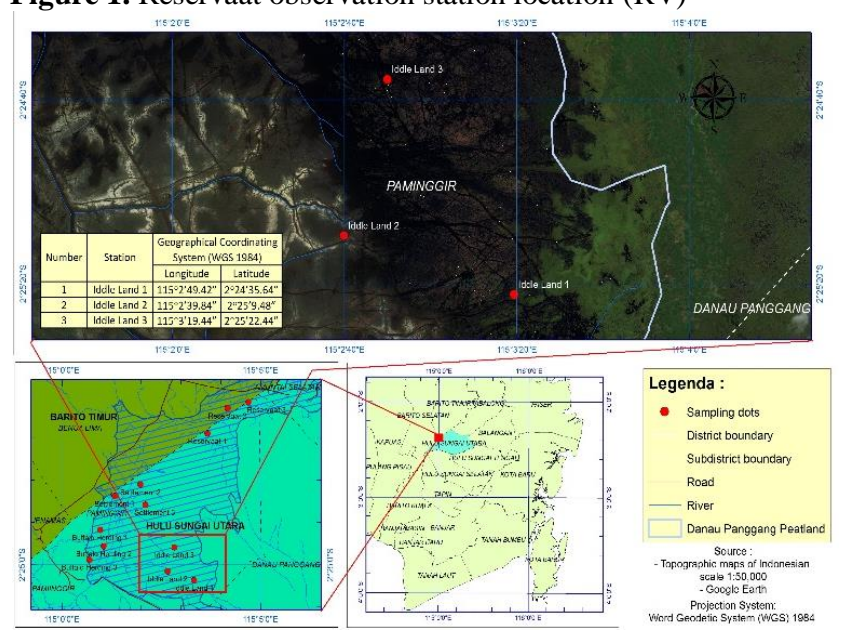


Figure 2. Idle land observation station location (TA)

\section{Water quality}

The analysis of water quality included observing the brightness, $\mathrm{pH}$ measured with $\mathrm{pH}$ meter, DO measure with DO meter, and BOD measured with Winkler titration. All of these were calculated using the STORET method, which is a method to compares water quality data with water quality standards (based on Government Regulation number 82/2001) adjusted for their designation to determine the status of water quality taken as supporting data together with fish sampling.

\section{RESULTS AND DISCUSSION}

\section{The number of piscivorous fish at observation station}

Piscivorous fishes caught in the Danau Panggang Peatland at the RV station originated from nine species of six families, including Cryptopterus spp., Pangasius nieuwenhuisii, Chanastriata, Anabas testudineus, Pangasius sp., Mastecembelus erythrotaenia, Macrognathus aculeatus, Mystus nigriceps, and Mystus nemurus. Those caught at the TA station were from six species of four families, including Cryptopterus spp., Pangasius nieuwenhuisii, Anabas testudineus, Pangasius sp., Mystus nigriceps, and Mystus nemurus. The piscivorous fishes caught in this investigation were far more diverse than in Slamat (2015), which only had four species, as well as Mijani et al. (2011), in the Bangkau Peatland, South Hulu Sungai, which only had two species. These numbers at each station, observed at the 4 times of sampling are shown in Table 1.

Of the 57 fish caught at the RV station, $96 \%$ had stomachs containing food. The TA station, $97 \%$ of the 39 fish caught were found to have food in the stomach. Therefore, the phenomenon of no food was found in the stomach of fishes, because of food had been properly digested or they were caught in a state of hunger (Titrawani and Sawalia 2013).

\section{Index of preponderance}

The food composition in the stomach contents of piscivorous fish was unexpected, as generally, based on the several food habits of piscivorous species (Joyce et al. 2002). The stomach contents at both stations were dominated by the Phytoplankton group of the Chrysophyta Phylum. Moreover, at RV, $89 \%$ of the IP was dominated by Diatoms and Navicula Divisions, while at TA, $83 \%$ was Diatom Division (Figures 3 and4). Therefore, the main diet was about $>25 \%, 4-25 \%$ was supplementary, and $<4 \%$ was complimentary food (Effendi 2002).

Table 1. Species and number of piscivorous fish at each observation station

\begin{tabular}{lcccc}
\hline \multirow{2}{*}{ Fish species } & RV (number) & \multicolumn{2}{c}{ TA (number) } \\
\cline { 2 - 5 } & Caught & $\begin{array}{c}\text { Stomach } \\
\text { with } \\
\text { contents }\end{array}$ & $\begin{array}{c}\text { Caught } \\
\text { Stomach } \\
\text { with } \\
\text { contents }\end{array}$ \\
\hline Anabas testudineus & 9 & 9 & 9 & 9 \\
Channa striata & 7 & 6 & - & - \\
Cryptopter spp. & 12 & 12 & 12 & 12 \\
Macrognathus aculeatus & 6 & 6 & - & - \\
Mastecembelus erythrotaenia & 2 & 2 & - & - \\
Mystus nemurus & 5 & 4 & 3 & 3 \\
Mystus nigriceps & 12 & 12 & 11 & 11 \\
Pangasius nieuwenhuisii & 1 & 1 & 1 & - \\
Pangasius sp. & 3 & 3 & 3 & 3 \\
Total & 57 & 55 & 39 & 38 \\
\hline & & & &
\end{tabular}

Table 2. Parameters of water quality at each sampling and control station

\begin{tabular}{lcccccc}
\hline Parameter & $\begin{array}{c}\text { Station/ } \\
\text { month }\end{array}$ & July & Oct & Jan & Apr & $\begin{array}{c}\text { Government } \\
\text { Reg. No. } \\
\text { 82/2001 }\end{array}$ \\
\hline Temp. & TA & 31.85 & 29.23 & 28.07 & 30.03 & Deviation 3 \\
$\left({ }^{\circ} \mathrm{C}\right)$ & RV & 29.8 & 30.27 & 29.4 & 30.97 & \\
pH & TA & 6.22 & 6.25 & 5.91 & 6.71 & $5-9$ \\
& RV & 4.61 & 5.96 & 4.62 & 4.94 & \\
Brightness & TA & 81.5 & 42.7 & 115 & 22.3 & $>30$ \\
$(\mathrm{~cm})$ & RV & 9 & 22.7 & 29.3 & 6 & \\
DO & TA & 2.3 & 2 & 1.6 & 1.8 & $\geq 4$ \\
$(\mathrm{mg} / \mathrm{L})$ & RV & 5.2 & 4.9 & 2.8 & 5.4 & \\
BOD & TA & 15.77 & 22.52 & 13.81 & 10.40 & $\leq 3$ \\
$(\mathrm{mg} / \mathrm{L})$ & RV & 15.80 & 16.52 & 13.51 & 15.93 & \\
\hline
\end{tabular}




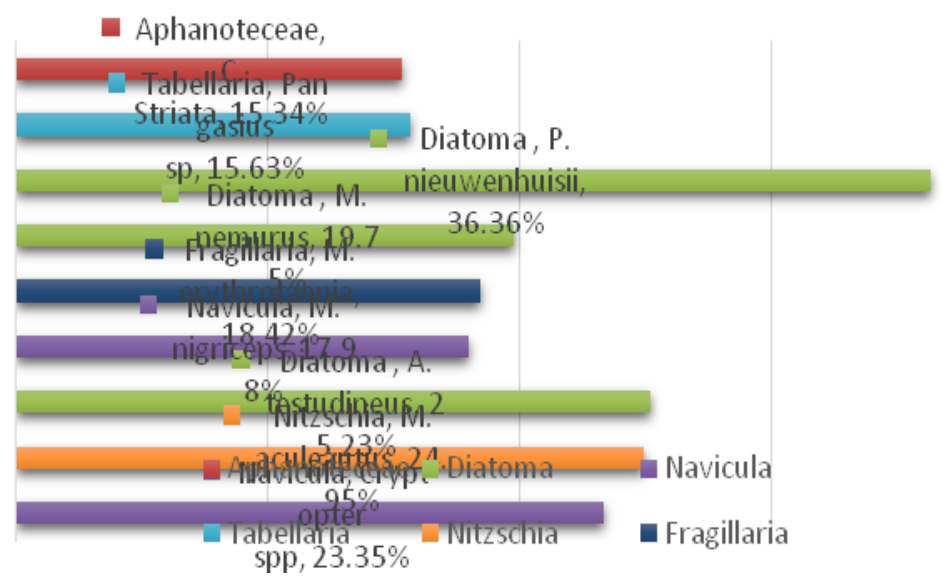

Figure 3. Index of Preponderance (IP) of piscivorous fish caught at the RV station

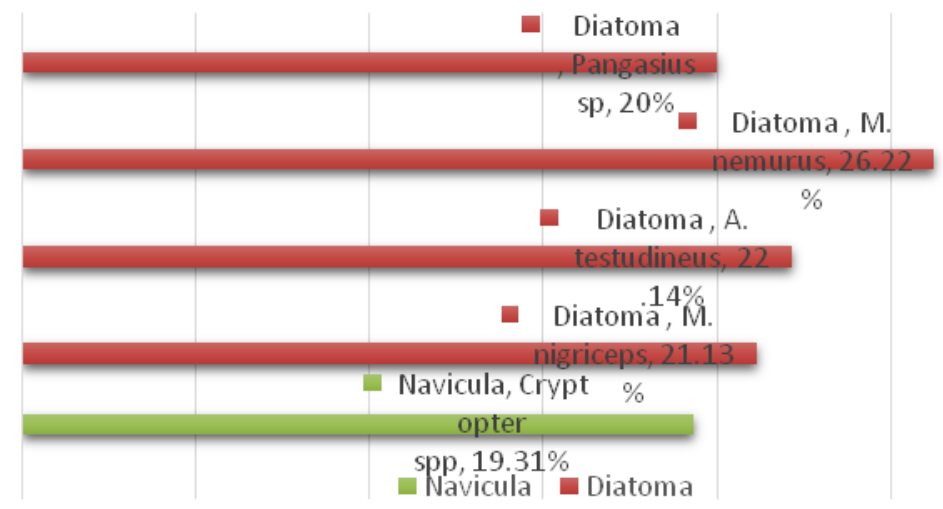

Figure 4. Index of Preponderance (IP) of piscivorous fish caught at the TA station

\section{Water quality parameter}

The relationship between the stomach contents of the piscivores and aquatic habitat quality is very tight. The results of this study showed the dissolved oxygen (DO) value to be low, hence, not fulfilling the standards required based on the Government Regulation number 82/2001. This further, increases the BOD level, and the other parameter evaluated, including temperature, brightness, and acidity level $(\mathrm{pH})$ also did not meet the specifications (Table 2). Meanwhile, the shallow depth of 1-3 m caused very turbid waters that were brown, grey, and up to black, which makes it not surprising to find the blackfish group dominating peat peatland waters (Annual Report on Fisheries Statistics 2018).

Components of water quality encompassing temperature, brightness, $\mathrm{pH}, \mathrm{DO}$, and $\mathrm{BOD}$ are limiting factors for peatland waters. Therefore, the extreme conditions in the "Danau Panggang" Peatland subsequently led to limited availability of natural food choices for piscivorous fishes. In addition, their adaptation process was the reason why stomach contents tend to be dominated by the phytoplankton group, which ought not to be. RV Station is a deep peatland area that is closed, where and also where no fishery activities are permitted to be conducted. This is, therefore termed a conservation zone, although, from the results of IP and water quality analysis, the water quality was also observed to be extreme, limiting the food choices for piscivorous fish.

TA Station is a deep area with no activity, as it is only a route of transportation for fishing boats or passenger transport ships. In addition, its condition tends to be clearer than locations with activity because it is not filled with water plants, hence, sunlight is able to enter through the surface. However, similar to RV, the water quality was also extreme, and a limitation in food choices also caused changes in feeding habits concerned with adaptation.

\section{Discussion}

In general, fishes are heterotrophic organisms in the level of secondary productivity in waters, while the piscivorous species are secondary consumers in a community, which depends on the number of primary consumers in the food chain. Therefore, their abundance cannot be separated from the food sources, including small fish or plankton. Hence, a large quantity of small fish and planktons positively impacts the organisms that occupy the next position in the structure of the food chain (Sanyu and Schagerl 2010; Slamat 2015).

Food consumed is, therefore, related to its availability in the waters, although not all types, including small fish, phytoplankton, and zooplankton, are utilized by fish. In addition, the data obtained were influenced both by the 
types of food present in the waters, and the periodicity of feeding, stomach volume, and food selection (Frandy 2009; Nurnadia et al. 2013). Index of Preponderance (IP) has been applied as a diet habit indicator of fish. The ecosystem characteristics of "Danau Panggang" Peatland which indicated by the extreme and shallow water quality causes a limitation in the availability of piscivorous fish foods.Food eaten by fish is identified from the analysis of their stomach contents. Therefore, a lot of food organisms existing in the waters does not necessarily make it an important part of the composition of the fish diet. Hence, they are said to choose and this discovery tends to take the largest part of the content (Index of Preponderance) in their stomach (Sofarini et al. 2019).

Of the total 96 fish caught, only 2 had stomach contents maintaining the expected profile of piscivorous fish species. Meanwhile, at the RV station, Pangasius nieuwenhuisii was found to contain Filopaludina javanica, and at TA, Cryptopter spp was observed to comprise of Osteichilus hasselti. Therefore, differences in the type and amount of food ingested were said to occur due to differences in the distribution of edible organisms in each area, while the factors that affect preferences include the distribution of food organisms, their availability, selection of types, and the aquatic environment (Effendi 2002). Hence, the same species of fish in different habitats and life phases consume different types of food. That is a form of adaptation toward the availability of nutrient sources and water quality in the habitat (Sanchez-Gonzales et al. 2001; Suryandari and Krismono 2011).

The dominance of Chrysophya Phylum phytoplankton of the Diatom Division indicates its important role as a primary producer in the carbon cycle of the food chain (de Jonge and de Jong 1995; Suwartimah et al. 2011), and is also because it is an essential food source for surfacedwelling animals (crawling on the surface) and deposit feeder. Furthermore, they serve in sediment stabilization (Padang et al. 2014), and are also normally used as alternatives in monitoring the water conditions by observing certain species in the community structure. In addition, Diatoms contribute to environmental conditions as it is widely distributed, and some of its species have special tolerance toward ecological changes (Suwartimah et al. 2011), and they also contribute to aquatic productivity (Padang 2012). These organisms serve as food consumed by most fishes, including the piscivorous fishes in Danau Panggang Peatland, and their centric form is preferred in comparison with other phytoplankton with filament (Padang et al. 2014). Therefore, the phenomenon where fish are lesser in quantity within the stomach contents of the fish investigated was due to the unintentional phytoplankton ingestion during the eating activity. Furthermore, the preference of diatom was because of the limited food choices, and the environmental conditions of waters were observed to be quite extreme.

A distinctive characteristic of the peat peatland ecosystem is that it experiences deepwater periodically, which occurs during the rainy and low tide seasons in the summer. According to Junk et al. (1989), these fluctuations are as a result of an overflow from rivers, lakes, and/or rainwater, while in the "Danau Panggang" Peatland, it was due to the water run-off from the Barito and Negara Rivers, which occurs during the rainy season. This flow upstream carrying organic materials, causing an increase in the fertilization process of the peatland, while during the long summer, siltation occurs. Therefore, their condition, which involves richness in organic material, makes the decomposer play an extreme role in the process of putrefying the organic materials. Meanwhile, some fish species are able to adapt to this oxygen-deficient ecosystem, as seen in the Danau Panggang Peatland. Hence, the formation of the labyrinth organ (Sloman and Wilson 2006) provides their ability to survive.

In conclusion, the profile of stomach contents in piscivorous fish at two stations of the Danau Panggang Peatland was dominated by phytoplankton of Chrysophyta Phylum. Furthermore, at the RV station, 89\% was dominated by Diatom and Navicula divisions, while TA contained $83 \%$ Diatom Division. Their stomach contents ought to be dominated by small fish. This was due to the adaptation process to extreme environmental conditions of peat peatland waters, as the parameters of temperature, brightness, $\mathrm{pH}, \mathrm{DO}$, and BOD. In addition, some species that were caught possessed additional respiratory equipment, which was in the form of a labyrinth. This was to overcome the oxygen deficit contained in the body of water, although it is not owned by planktivorous fish, hence, the structure of the food chain was not ideal.

\section{ACKNOWLEDGEMENTS}

The author expresses her gratitude to the DRPM Kemenristekdikti of the Doctoral Dissertation Grant scheme for financing this study completely, and also to the Doctoral Program in Fisheries and Marine Sciences, Brawijaya University, Malang, Indonesia.

\section{REFERENCES}

Annual Report on Fisheries Statistics. 2018. Dinas Perikanan dan Peternakan Kabupaten Hulu Sugai Utara, Amuntai. [Indonesian]

Bayurini DH. 2006. Hubungan Antara Produktivitas Primer Fitoplankton dengan Distribusi Ikan di Ekosistem Perairan Rawa Pening Kabupaten Semarang. [Hon. Thesis]. Universitas Negeri Semarang, Semarang. [Indonesian]

Beamish RJ, Gao Y. 2003. Stable isotopic composition of otoliths from tagged Pacific halibut, Hippoglossus stenolepis. Environ Biol Fish 67 (3): 257-263.

Beveridge I, Neifar L, Euzet L.2004.Eutetrarhynchidcestodes from Atlantic and Mediterranean elasmobranch fishes, with the description of two new species of Dollfusiella Campbell \& Beveridge, 1994 and redescriptions of Prochristianella papillifer (Poyarkoff, 1909) Dollfus, 1957 and Parachristianella trygonis Dollfus, 1946. Syst Parasitol 59 (92): 81-102.

de Jonge DJ, de Jong VN. 1995. Dynamics and distribution of microphytobenthic chlorophyll-a in the Western Scheldt estuary (SW Netherlands). Hydrobiologia 311: 21-30.

Dubiaski-Silva J, Masunari S. 2008. Natural diet of fish and crabs associated with the phytal community of Sargassum cymosum C. Agardh, 1820 (Phaeophyta, Fucales) at Ponta das Garoupas, Bombinhas, Santa Catarina State, Brazil. J Nat Hist 42 (27-28): 19071922 
Effendi MI. 2002. Biologi Perikanan. Yayasan Pustaka Nusantara, Jakarta. [Indonesian]

Frandy T. 2009. Ecology and identity in the Northwoods: Finnish Americans poaching and techniques and narratives. In: Eliason E, Cutchins D (eds.). Wild Games: Interdisciplinary Approaches to Hunting and Fishing in North America. University of Tennessee Press, Knoxville, TN.

Ishii H, Tanaka F. 2001. Food and feeding of Aurelia aurita in Tokyo Bay with an analysis of stomach contents and a measurement of digestion times. Jellyfish Blooms: Ecol Soc Importance 451: 311-320.

Joyce WN, Campana SE, Natanson LJ, Kohler NE, Pratt Jr HL, Jensen CF. 2002. Analysis of stomach contents of the porbeagle shark (Lamnanasus Bonnaterre) in the northwest Atlantic. ICES J Mar Sci 59 (6): 1263-1269.

Junk WJ, Bayley PB, Sparks RE. 1989. The flood pulse concept in riverfloodplain systems. Can J Fish Aquat Sci 106: 110-127.

Mijani R, Ahmad R, Herliwati H. 2011. Karakteristik Eko-Biologis Perikanan Beje di Kawasan Rawa Danau Bangkau Kalimantan Selatan. Universitas Lambung Mangkurat, Banjarmasin. [Indonesian]

Mohan MV, Sankaran TM. 1988. Two new indices for stomach content analysis of fishes. J Fish Biol 322 (2): 289-292.

Moore J, de Ruiter PC. 2012. Energetic Food Webs: An Analysis of Real and Model Ecosystems. Oxford University Press, Oxford.

Mora C. 2015. The Ecology of Fishes on Coral Reefs. Cambridge University Press, Cambridge.

Noor M. 2007. Lebak Peatland, Ecology, and Its Using. PT. Raja Grafindo Persada, Jakarta. [Indonesian]

Nurnadia AA, Azrina A, Amin I, Yunus MAS, Effendi MHI. 2013 Mineral contents of selected marine fish and shellfish from the west coast of Peninsular Malaysia. Int Food Res J 20 (1): 431-437.

Padang A, Lukman E, Sangadji M. 2014. Komposisi makanan dalam lambung teripang. J Ilmiah Agribisnis Perikanan 7 (2): 26-30. [Indonesian]

Padang A. 2012. Peranan diatom bentik bagi produktivitas primer di lingkungan bentik. J Bimafika 3 (2): 272-278. [Indonesian]

Pawson MG, Pickett GD, Leballeur J, Brown M, Fritsch M. 2007 Migrations, fishery interactions, and management units of sea bass (Dicentrarchus labrax) in Northwest Europe. ICES J Mar Sci 64 (2): 332-345.

Sanchez-Gonzales S, Ruiz-Campos G, Contreras-Balderas S. 2001 Feeding ecology and habitat of the threespine stickleback,
Gasterosteusaculeatus microcephalus, in a remnant population of northwestern Baja California, México. Ecol Freshw Fish 10 (4): 191197.

Sanyu AG, Schagerl M. 2010. Phytoplankton productivity in newly dug fish ponds within Lake Victoria Wetlands (Uganda). Afr J Environ Sci Technol 4 (5): 30-40.

Scholz M, Trepel M. 2004. Water quality characteristics of vegetated groundwater-fed ditches in a riparian peatland. J Sci Total Environ 332 (1-3): 109-122.

Slamat S. 2015. Plankton fertility in supporting fish productivity in monotonous peatland in Hulu Sungai Utara Regency. Trop Wetland J 1 (1): 25-32.

Sloman KA, Wilson RW. 2006. Behavior and Physiology of Fish. Elsevier Academic Press, California, USA.

Sofarini D, Herawati EY, Mahmudi M, Asus MSH, Amin M. 2019. Laisfish stomach content composition (Cryptopter spp.) and characteristics of Rawa Danau Panggang South Kalimantan. Russ J Agric Socio-Econ Sci 1: 533-539

Sulistiyarto B. 1998. Pengaruh Beberapa Komponen Habitat terhadap Kelimpahan Anak Ikan Seluang (Rasbora sumatrana) di Rawa Berengbengkel Palangkaraya. [Thesis]. Program Pascasarjana, Institut Pertanian Bogor, Bogor. [Indonesian]

Suryandari A, Krismono. 2011. Beberapa aspek biologi ikan manggabai (Glossogobius giuris) di Danau Limboto, Gorontalo. BAWAL Widya Riset Perikanan Tangkap 3 (5): 329-336. [Indonesian]

Suwartimah K, Widianingsih, Hartati R, Wulandari SR. 2011. Komposisi jenis dan kelimpahan diatom bentik di Muara Sungai Comal Baru Pemalang. BAWALWidya Riset Perikanan Tangkap 16 (1): 16-23. [Indonesian]

Titrawani E, Sawalia RU. 2013. Analisis isi lambung ikan senangin (Eleutheronema tetradactylum Shaw) di perairan Dumai. Al Kauniyah J Biol 6 (2): 85-90. [Indonesian]

Voellmy IK, Purser J, Flynn D, Kennedy P, Simpson SD. 2014. Acoustic noise reduces foraging success in two sympatric fish species via different mechanisms. J Anim Behav 89: 191-198.

West KL, Walker WA, Baird RW, Mead JG, Collins PW. 2017. Diet of Cuvier's beaked whales Ziphius cavirostris from the North Pacific and a comparison with their diet world-wide. Mar Ecol Prog Ser 574: 227-242. 